\title{
THE CASE STUDY OF CANVAS MODEL OF RUBBER TIRE RECYCLING IN TURKEY
}

\section{Deniz Horuz*, Selim Çörekçioğlu}

\author{
Szent Istvan University, Gödöllö, Hungary
}

\begin{abstract}
Nowadays, problems related to waste tires are increasing. The worn-out vehicle tires are abundant, together with worthless waste. Besides, it causes environmental pollution and it harms human health. Nowadays, too many car tires are being produced and the old tires are beginning to become a problem. The old tires can be decomposed or burned to get energy or heat. One of the most effective ways to get rid of these problems is to recycle the waste tires and use them in a different area. In this paper, the study was based on basic information about the waste tires and its recycling technologies. Based on this study, the canvas model has been created to show how to run a business with recycling the worn-out tires.
\end{abstract}

Keywords: circular economy; renewable resources; business model; canvas model; recycling

Products made from natural and synthetic rubbers that consist of highmolecular-structure polymers, which are highly durable in terms of environment and their waste, can hardly disintegrate in the environment. (Gönüllü, 2014). The automotive industry, which is one of the main sectors that drive the country's economies, is also involved in the automotive supply industry and tire industry, where about $85 \%$ of the rubber is consumed (Adhikari, 2000).

Rubber could be divided into two groups, natural rubber and synthetic rubber. Despite the fact that there could be various types of synthetic rubber, the majority of them are styrene-butadiene rubber (SBR) and polybutadiene rubber (PBR-CBR) (Ünlü, 2006).

The qualities of rubber consist of high flexibility, high strength, low deformation and spreading, good dynamic properties, easy handling, good tear and abrasion resistance, and polar liquid resistance. The rubber used in automobile tires is flexible, durable, and abrasion-resistant (Korkmaz and Türer, 2005).

There are almost 30 million worn-out tires left in Turkey each year. There are two major environmental hazards of worn-out tires. One of them is fires and the other is epidemic illness caused by insects that live in these worn-out tire masses. Diseases caused by insects, which live in the worn-out tire mass, happen usually after the rain (Erdem, 2015).

When the tire waste is stored separately from the other waste, the hazards become bigger. There is enough oxygen in all the tires to cause a fire. For instance, one worn-out tire fire lasted about 9 months in Winchester, Virginia, USA (Lagrega, 1994).

Methods of recycling the used tires are becoming widespread today. Used tires are recycled for various formats, from whole to powder (Akdemir and Karabork, 2013).
It has been suggested that if the old tires are used in asphalt construction, 80,000 tons of old tires will be added to the economy per year and traffic accidents will be reduced, because if the recycled materials of the used tires are mixed with asphalt, it will provide better grip for cars (Catakli and Erguder, 2019).

\section{Material and methods}

Pyrolysis is one of the methods which are used to recycle the old tires into oil. During the pyrolysis process, worn-out tires are kept under a high temperature and pressure, so they turned into gas oil. The worn-out tires turn into carbon black, gas, steel, and oil after pyrolysis and then they are melted. A different process is defined for pyrolysis and melting in different quantities. If the temperature increases, more gas is produced. If the temperature decreases, more oil is produced (Abdul-Rahman, 2014).

Table 2 Products Obtained from Pyrolysis (\%)

\begin{tabular}{|l|c|}
\hline Product & Quantity (\%) \\
\hline Solvents & 3 \\
\hline Heavy oils & 1 \\
\hline Middle oils & 2 \\
\hline Light oils & 20 \\
\hline Steel & 12 \\
\hline Fuel for the pyrolysis process & 12 \\
\hline Gas & 13 \\
\hline Ash & 37 \\
\hline
\end{tabular}

Source: Storm, 1998

Table 1 Properties of Rubber Types

\begin{tabular}{|c|c|c|c|c|c|c|}
\hline Characteristics & UNIT & SBR 1502 & SBR 1712 & SBR-1712NF & CBR 1203 & CBR 1220 \\
\hline Volatile substance & $\% w$ & $1.5 \max$ & $0.75 \max$ & $0.75 \max$ & $0.75 \max$ & $0.75 \max$ \\
\hline Total ash & $\% w$ & $0.3 \max$ & $1.5 \max$ & $1.5 \max$ & $0.3 \max$ & $0.3 \max$ \\
\hline Mooney viscosity & $\mathrm{ML} / 4^{\prime} 100^{\circ} \mathrm{C}$ & $\mathrm{ML} / 4^{\prime} 100^{\circ} \mathrm{C}$ & $46-56$ & $46-57$ & $39-51$ & $39-49$ \\
\hline Tensile stress at break & $\mathrm{kg} / \mathrm{cm}^{2} 35^{\prime} / 145^{\circ} \mathrm{C}$ & $220 \mathrm{~min}$ & $175 \mathrm{~min}$ & $175 \mathrm{~min}$ & $125 \mathrm{~min}$ & - \\
\hline Elongation at break & $\% 35^{\prime} / 145^{\circ} \mathrm{C}$ & $380 \mathrm{~min}$ & $500 \mathrm{~min}$ & $500 \mathrm{~min}$ & $380 \mathrm{~min}$ & - \\
\hline
\end{tabular}

Source: Lagrega, 1994 
According to the Scrap Tire Management Council, 4 liters of oil, $3 \mathrm{~kg}$ of carbon black, $1.5 \mathrm{~kg}$ of gas and $1 \mathrm{~kg}$ of steel and ash can be obtained from a tire. The oil and gas obtained from a tire are sold as low-quality fuel (Guograng and Eggers, 2012).

There are some changes in the characteristics of the waste tires while recycled into different sizes. To use a waste tire as another industrial product, its size is required to be reduced. During the process, five different sizes of waste rubber can be obtained from an entire tire. It can be seen in Figure 1 below.

\section{Understanding the concept of Canvas Model by an example of Worn-Out Tires}

A business plan of the worn-out tires, which are creating an environmental problem in the world, has been created. If the worn-out tires are included in the recycling system, both the negative effects on the environment will be prevented and an economic value will be provided.

It is important to ensure that the old tires, and especially the worn-out tires, are recycled and become useful to prevent destruction of the environment. Tires consist of non-renewable resources such as natural rubber, synthetic rubber, carbon black, steel, lubricants, and various chemicals. Hence, this kind of material will need more than 500 years to completely disappear from nature (Morawetz, 2000).

Due to the project, tires that have completed their life will be recycled and they will contribute to the country's industry and economy.
Considering the key activities of waste tires, the pyrolysis process is applied. Then, the waste tires are recycled into different products such as oil, carbon black, rubber, waste steel wire and gas. Carbon black, which is the result of the pyrolysis process, is much more economical than other carbon black, so it is very suitable to be used as a filler and additive material in certain production areas. The gas, which cannot be condensed during the pyrolysis, can be used instead of natural gas and propane, if it can be stored in suitable conditions. It can be burned in burners to generate electricity and heat. Waste oils can be used as industrial fuels after certain operations - either by mixing the fuels or directly as fuel oil in electric power plants. Granules and powdered rubber raw materials obtained from the old tires can be used on sports fields. Furthermore, it can be used in landscaping the areas of cities. It can be also used on roads by mixing with asphalt or it can be used in footwear production. It can even be used as electricity.

Reasons of the tire recycling are:

$\square$ The sector is profitable.

$\square$ The cost of raw materials is very low.

$\square$ The amount of raw material is very high.

$\square$ It protects natural resources.

$\square$ It makes it possible to produce secondary raw materials.

$\square$ Provide the development of the trade.

$\square$ It creates employment.

$\square$ It reduces import expenses.

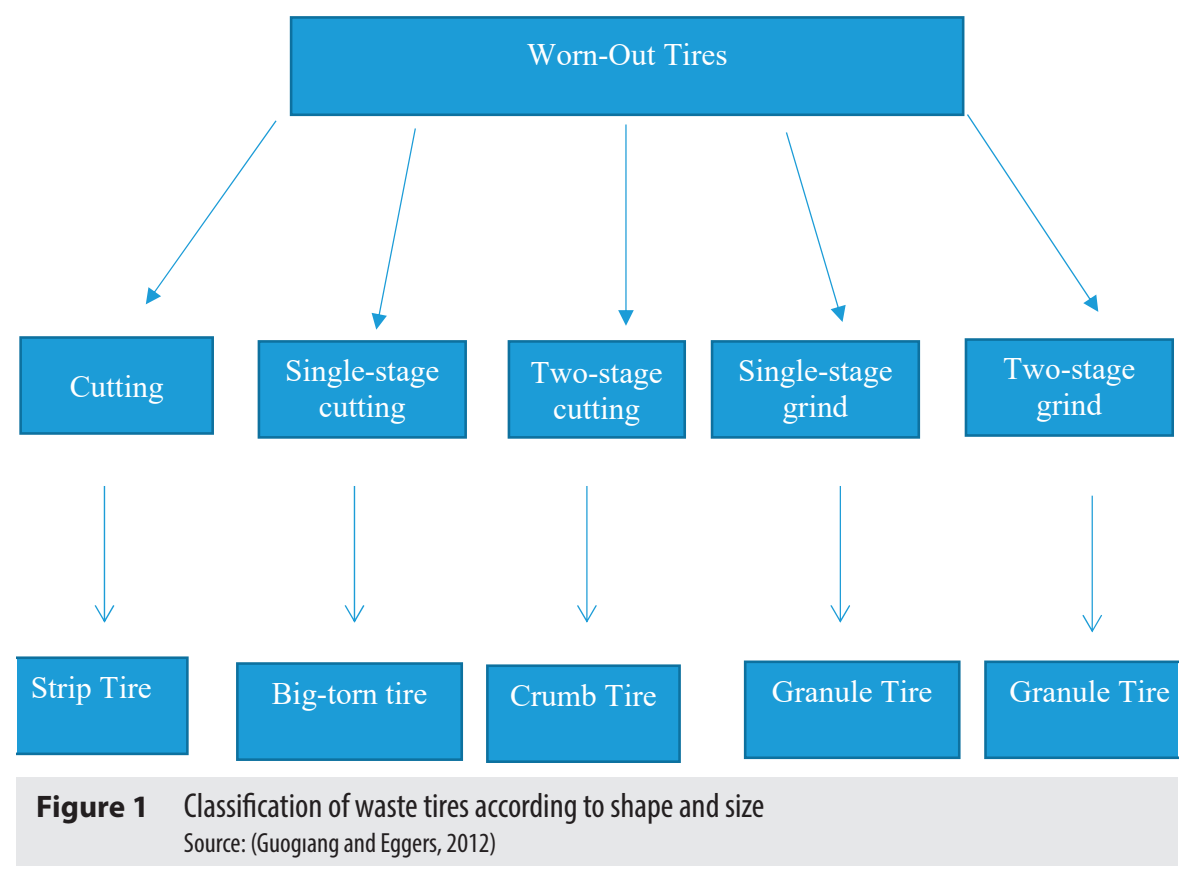

$\square$ It provides the opportunity for exporting.

$\square$ It contributes to the country's economy.

Description of the market of the old tires recycling is carried out within the framework of the Ministry of Environment and Urbanization legislation. According to the current legislation, both the tire rubber producer and importer are responsible for the recycling of the old tires in Turkey. These companies are responsible for the recycling of the $80 \%$ of the tires that they produced or sold in the market in the previous year. The companies can fulfill this responsibility either by themselves or they can carry it out with another company or organization. Approximately $70 \%$ share of the old tire decomposition and production in Turkey belong to the Rubber Manufacturers Association members. The remaining 30\% share of the old tires will be divided among the tire manufacturer and importer. It is estimated that there are approximately 300,000 tons of wornout tires left in Turkey. In terms of economy and environment, it is particularly important to recycle the tires.

According to the Regulation of the old tires, each producer or importer who sells tires to the market must collect and recycle a certain number of tires, which were sold to the market in the previous year. This amount has reached $80 \%$ in Turkey (Karaağaç, Kalkan and Deniz, 2015).

The Potential Customers are:

$\square$ Highways Regional Offices.

$\square$ Municipalities.

$\square$ Insulation factories.

$\square$ Cement factories

$\square$ Energy factories.

$\square$ Aluminum factories.

$\square$ Shoes and boots companies.

$\square$ Automotive industry.

Advantages of Recycling the Worn-out Tires are:

$\square$ Contribution to the protection of the natural resources.

$\square$ Contribution to the cleanliness of the environment.

$\square$ Ensuring the development of trade.

$\square$ Creating employment.

$\square$ Reducing import costs.

$\square$ Providing opportunity for exporting.

$\square$ Using no chemical additives in the process.

$\square$ Simplicity and exceptionally low operating costs.

$\square$ Creating an alternative energy source and thus, reducing petrol dependency. 
$\square$ Providing great economic and social facilities to the government and local governments.

Disadvantage of Recycling the Worn-out Tires are:

$\square$ As the sector is low-cost, several potential investors can be attracted by this sector. Then, it causes an increase in the number of opponents.

$\square$ Insufficient vocational training, qualification staff.

$\square$ Sensitivity in economic crises.

\section{$\square$ Bureaucracy.}

Tires with an outer depth fall below 1.6 millimeters and/or which cannot be used under the vehicle are considered as worn-out tires. Authorized companies collect the old tires from other companies and take them to the civic amenity center (Ünlü, 2006). In granular plants, the old tires are granulated into pieces with various millimeter sizes. Granules are used in synthetic pitch, walking trail, for safer ground materials in children's playgrounds, etc. (Akdemir and Karabork, 2013). For the pyrolysis process, the old tires must be decomposed and prepared. During the pyrolysis process, they are kept under a high temperature and pressure, so they turn into gas oil. The produced oil is mainly used as fuel in the production of electric energy and industrial plants (Abdul-Rahman, 2014).

Concerning the cost structure of the worn-out tires, after the old tire is purchased at the price determined by the Tire Industrialists Association; general management, marketing costs, tax, etc., which are fixed, will be all added and thus, the product price will be determined also by the demand and the competitors. If the demand is low, discount policy and promotional activities will be carried out.

Customer Channels and Customer Relationships:

$\square$ The company will provide face to face meetings with the customer at their office.

$\square$ Customer satisfaction is important. A satisfied customer will promote our company.

$\square$ Billboards will be created and they will be both remarkable and provide customers with clear information.

$\square$ Promoting materials such as handbags, business cards and brochures will be distributed. $\square$ A website will be available to obtain information and to promote the company.

Service presentation process of the raw material will be reached from the contracted companies. The selling performance will be tested for 1 year. Then, long-term agreements will be signed with the customers. Regarding the demand and need, it will be decided how many products will be produced. After selling the products, we will start to accumulate stock for the further demand. Revenue streams of products are delivered to the consumer, or the customers come to buy the products on the spot. When the online sales start, the products will be delivered to the customers via our shipping company. Orders will be received from the customers, who will also provide their address information. Payments will be made by the customers either by cash, credit card or online.

This paper aims to carry out research of the rubber tire recycling, together with an empirical literature review of the waste tires recycling and recycling purpose of the worn-out tires. Besides this empirical research, there is a case study, which clarifies how to run business with a relation to recycling the rubber tires in Turkey. For such case study, a canvas business method has been created to understand the concept of business.

\section{Results and discussion}

To sum up, we all know how important is to use the recycled products for the protection of the environment. Furthermore, it helps to develop the country economically. As we can see below, there is a Table of the Canvas method. Canvas model helps us to create a business model easily. Those nine dimensions of the canvas model show us, how the structure should look like in the business. This shows how we can run a business with a use of the canvas method, concerning the rubber tire recycling.

\section{Conclusions}

In the paper, the basic features of the business model have been presented to develop a better understanding of the concept. Technologies related to the recycling of the waste tires are investigated. Based on this study, a canvas

Table 3 Canvas Model of the Rubber Tire Recycling

\begin{tabular}{|c|c|c|c|c|}
\hline Key partners & Key activities & Value proposition & Customer relationships & Customer segments \\
\hline $\begin{array}{l}\text { rubber manufacturers association } \\
\text { rubber tire dealer: } \\
\text { Bridgestone } \\
\text { Michelin } \\
\text { Continental }\end{array}$ & $\begin{array}{l}\text { collecting rubber tire: } \\
\text { decomposition } \\
\text { production } \\
\text { marketing } \\
\text { customer support }\end{array}$ & \multirow[t]{2}{*}{$\begin{array}{l}\text { price } \\
\text { cost reduction } \\
\text { protection of natural resources } \\
\text { import costs reduction } \\
\text { easy usage of the product }\end{array}$} & $\begin{array}{l}\text { customer service } \\
\text { supporting customers } \\
\text { and suppliers via social media } \\
\text { promotional offers }\end{array}$ & $\begin{array}{l}\text { general Directorates of highways } \\
\text { municipalities } \\
\text { insulation sectors } \\
\text { energy sectors } \\
\text { aluminum factories }\end{array}$ \\
\hline $\begin{array}{l}\text { Pirelli } \\
\text { municipalities }\end{array}$ & $\begin{array}{l}\text { key resources: } \\
\text { brand } \\
\text { store } \\
\text { worn-out tires } \\
\text { machines } \\
\text { Ttansportation } \\
\text { vehicles (truck, work machine) } \\
\text { technical personnel and non- } \\
\text { qualified personnel }\end{array}$ & & $\begin{array}{l}\text { channels: } \\
\text { website } \\
\text { mobile applications } \\
\text { social media }\end{array}$ & $\begin{array}{l}\text { automotive industry } \\
\text { shoe producer } \\
\text { plastic bag producer } \\
\text { rubber tire producer }\end{array}$ \\
\hline
\end{tabular}


model was composed to understand how to run a business appropriately from the recycled tires.

Firstly, waste inventory must be made, as there is no clear data on the types and quantities of the hazardous waste in Turkey. According to the results of the inventory, it will be assumed that the waste management plans for an application on the regional level will be prepared more effectively by the authorities.

The implementation of the waste tire recycling practices in our country has become compulsory due to both economic and environmental factors. According to the characteristics of the city, waste management plans can be prepared at a local level to implement the local waste management plans. Considering the environmental and economic characteristics of the worn-out tires, recycling strategies must be well planned.

It is possible to reuse the waste tires by using some processes already explained in the introductory part. If the worn-out tires are recycled, it will create an added value. Waste tire recycling also provides great economic and social facilities to the countries' economies.

\section{References}

ABDUL-RAHMAN, F. 2014. Reduce, Reuse, Recycle: Alternatives for Waste Management. New Mexico : Nex Mexico State University, 2014.

ADHIKARI, B. 2000. Reclamation and Recycling of Waste Rubber. In Progress in Polymer Science, 2000, pp. 848-909.

AKDEMIR, A. - KARABORK, F. 2013. Atık Taşıt Lastiklerinin Parçalanması ve Lastik Tozunun Karakterizasyonu. In Erciyes Üniversitesi Fen Bilimleri Enstitüsü Fen Bilimleri Dergisi, 2013, pp. 29-40.

AMMONS, J. - MATHEWW, D. 1995. Reverse Production System Design and Operation for Carpet Recycling. In Submitted for publication consideration to the European Journal of Operational Research, 1995, pp. 547-567.

CATAKLI, T. - ERGUDER, T. H. 2019. Biyo-devulkanizasyon: Atık Lastik Yönetiminde Çevre Dostu Bir Yaklaşıım. In Ulusal Çevre Bilimleri Araşıırma Dergisi, 2019, pp. 20-34.

CSABA, F. - BÁLINT, H. - ROBERT, M. 2017. Business Model Innovation as a Tool to Establish Corporate Sustainability. In Visegrad Journal on Bioeconomy and Sustainable, 2017, pp. 77-92.
ERDEM, M. 2015. Industrial Waste Management. In Environment and Industry conference, Ministry of Environment, 2015, pp. 1-17.

GÖNÜLLÜ, M. 2014. Waste Tire Management. In Solid Waste Recycling Technologies Seminar, 2014, pp. 125-133.

GUOGIANG, L. - EGGERS, J. 2012. Development of waste tire modified concrete. In Cement and Concrete Research, 2012, pp. 2283-2289.

HEINE, H. 1993. Reducing Waste Through Reverse Logistics. In Foundry Management \& Technology, 1993, pp. 28-39.

KARAAĞAC, B. - KALKAN, M. E. - DENIZ, V. 2015. End of life tire management: Turkey case. In Journal of Material Cycles and Waste Management, 2015, pp. 577-584.

KORKMAZ, S. - TÜRER, H. 2005. Strengthening of Masonry Structures by Elastic ArtStretching Strips. In Middle East Technical University Publications, 2005, pp. 1-12.

KUMAR, S. 2006. Strategic alliance in a closed-loop supply chain, a case of the manufacturer, and eco-nonprofit organization. In Technovation, 2006, pp. 1127-1135.

KÜÇÜKGÜL, E. 2004. Hazardous Waste Management. In Ankara Chamber of Mechanical Engineers publications, 2004, pp. 25-32.

LAGREGA, M. 1994. Hazardous Waste Management. McGraw-Hill.

MORAWETZ, H. 2000. History of Rubber Research. In Rubber Chemistry and Technology, 2000, pp. 405-426.

OSTERWALDER, A. - PIGNEUR, Y. 2010. Business Model Generation. New Jersey : John Wiley \& Sons, Inc., 2010.

STORM, J. 1998. Application of a Reverse Logistics Model for Optimizing Scrap Tire Processing. Master of Science thesis submitted to the University of Texas at El Paso, 1998.

ÜNLÜ, H. 2006. Recycle of Hazardous Wastes in the Automotive Industry. Uludag University, 2006.

\section{Contact address}

Deniz Horuz, School of Management and Business Administration, Szent Istvan University, H-2100 Gödöllő, Páter Károly utca 1 Hungary, e-mail: dnzhoruz@gmail.com; Horuz.Deniz@hallgato.uni-szie.hu

JEL Code: Q2; Q5; M1 